\title{
Molecular Detection of CCR5 D32 Allele Gene Among Discordant HIV- Infected Couples in Kaduna State, Nigeria.
}

Daniel Abba Danboyi ( $\sim$ daniel_abba@yahoo.com )

Kaduna State College of Nursing and Midwifery Kafanchan.

\section{Research Article}

Keywords: Antiretroviral therapy, Discordance, HIV, CCR5 D32, Sexually transmitted infection

Posted Date: January 25th, 2022

DOI: https://doi.org/10.21203/rs.3.rs-1292860/v1

License: (c) (i) This work is licensed under a Creative Commons Attribution 4.0 International License.

Read Full License 


\section{Abstract \\ Background}

Discordance is a situation where one partner is HIV positive while the other remains negative within couples and the CCR5 D32 gene is the mutant variant of the CCR5 wt. fusion protein which confers resistance to HIV infection. The research was conducted for molecular detection of CCR5 D32 allele gene in discordant HIV-infected couples in Kaduna State Nigeria. The objective of the research was to establish the incidence of discordance among HIV infected couples in Kaduna state and to determine the frequency of CCR5 D32 mutant allele gene among discordant HIV- infected couples. Existing literature has it that HIV discordance is low in several communities and CCR5 mutation is very rare in Africa; this underscores the need to establish the real situation in Nigeria.

\section{Methods}

A total of 158 couples and 317 individuals were recruited for the survey using a Stratified sampling technique. The 23Local Government Areas of Kaduna State were divided into 3 strata (senatorial Zones). These respondents accessed treatment at 9 HIV treatment centers in 9 Local Government Areas of the 23Local Government Areas of Kaduna State. Blood test was conducted to confirm their HIV status and ensure they were discordant couples. Blood samples of negative partners were analyzed using Primers of CCR5 gene in the molecular laboratory.

\section{Results}

The results showed that more women 105(33.12\%) were HIV positive, and the HIV discordance prevalence for Kaduna State determined at $0.2 \%$. The results also showed from gel electrophoresis, that the frequency of CCR5 D32 allele gene in the population was $1.3 \%$, and there was no correlation between HIV discordance and CCR5 D32 allele gene- they both occur independently.

\section{Conclusions}

Low incidence of CCR5 D32 gene (1.3\%) was discovered within the population studied. However, high presence of this gene variant in the population would have been a starting point in the research for the ultimate goal of finding a final solution in the treatment of HIV- AIDS. It is hereby recommended that more research be conducted in other states of Nigeria, and other African countries to ascertain the present status of the frequency of CCR5 D32 allele gene.

\section{Introduction}


HIV(Human Immunodeficiency Virus) Discordance among infected couples is a common phenomenon in sub- Saharan Africa and this has always been a challenge in the struggle for HIV prevention and cure in the population. $(1,2)$ Discordant couples are those where one partner is HIV-infected while the other is not, whereas a couple is defined as two persons in an on- going sexual relationship and each of these persons is referred to as a "partner" in the relationship. (3) HIV Discordance usually occurs as a result of several factors: it may be from initial non disclosure before marriage or relationship, traditional marriages without pre- marital counseling and testing, latency in the event of infection before marriage, and accidental infection of a partner during course of marriage or sexual relationship. (4) The phenomenon of discordance among HIV infected couples has remained a mirage and a concept that needs to be unraveled. It has remained so for as long as the discovery of the mutant alleles of the CCR5 gene came to fore. The mutant allele concept is just one possibility for discordance; there could be other reasons such as reduced viraemia or innate resistance. Knowing that majority of HIV-1 infection that occurs in Africa is among individuals in stable sexual partnership; improving our understanding on the correlates of discordance will provide information on the dynamics and risk factors of couple transmission that can assist in the development of interventions to reduce transmission within couple relationships. Chemokine receptor type 5 otherwise called CCR5 or CD195 is a protein on the surface of white blood cells that participates in the immune system as it acts as a receptor for chemokines. (5) For human beings, the CCR5 gene that encodes the CCR5 protein is located on the short (p) arm at position 21 on chromosome 3. Extensive research has revealed to us that some particular populations have inherited the Delta 32 mutation, resulting in the genetic deletion of a portion of the CCR5 gene. Homozygous carriers of this mutation are resistant to $\mathrm{M}$ - tropic strains of HIV1-infection. $(6,7,8,9,10,11)$ Research has shown that CCR5 surface protein belongs to the beta chemokine receptor family of integral membrane proteins. (12) It is a $\mathrm{G}$ protein- coupled receptor which functions as a chemokine receptor in the Cystein-Cystein chemokine group. Reports have it that the CCR5 is mostly expressed on T cells, macrophages, dendritic cells, eosinophils, microglia and a subpopulation of either breast or prostate cancer cells. $(13,14)$ The mutant CCR5- $\triangle 32$ (or CCR5-D32 or CCR5 delta 32) is an allele of CCR5 $(15,16)$. CCR5 $\Delta 32$ is a 32 -basepair deletion that introduces a premature stop codon into the CCR5 receptor locus, resulting in a nonfunctional receptor. $(17,12)$ CCR5 is required for M-tropic HIV-1 virus entry. Some individuals that are homozygous (denoted $\Delta 32 / \Delta 32$ ) for CCR $\Delta 32$ do not express functional CCR5 receptors on their cell surfaces and are therefore resistant to HIV-1 infection, despite multiple high-risk exposures. (18) Individuals heterozygous $(+/ \Delta 32)$ for the mutant allele have a greater than $50 \%$ reduction in functional CCR5 receptors on their cell surfaces due to dimerization between mutant and wild-type receptors that interfere with transport of CCR5 to the cell surface. (19) Heterozygote carriers have been found to be resistant to HIV-1 infection relative to wild types and when infected, heterozygotes exhibit reduced viral loads and a 2-3-year-slower progression to AIDS relative to wild types. $(17,18,20)$ Heterozygosity for this mutant allele also has shown to improve one's virological response to anti-retroviral treatment. (21) The CCR5 $\Delta 32$ has an (heterozygote) allele frequency of $10 \%$ in Europe, and a homozygote frequency of $1 \%$. A few numbers of human beings show partial or apparently complete inborn resistance to HIV, the virus that causes AIDS. (22) The main mechanism for discordance is a mutation of the gene encoding CCR5, which acts as a co-receptor for HIV. Research reports an estimated proportion of people with some form 
of resistance to HIV to be fewer than $10 \%$. $(23,24,25)$ Some particular populations have inherited the Delta 32 mutation resulting in the genetic deletion of a portion of the CCR5 gene $(6,7,8,9,10,11)$. In a survey conducted by Solloch et al. (26), they reported a CCR5 D32 allele frequency $0 \%$ from blood donors in Africa. Hence, there is need to investigate, and see if this gene deletion is responsible for HIV discordance among the population in Kaduna State Nigeria.

\section{Materials And Methods}

\section{Study Area}

This study was conducted in HIV treatment centers situated in all general hospitals in Kaduna State. Kaduna State Nigeria is one of the 19 northern states of Nigeria and has long been seen as the Major capital of the northern region, and now the capital of the North West. (27) It is ranked 4th by land area and 3rd by population in Nigeria. The state capital was the former capital city of the British protectorate of Northern Nigeria (1923-1966) after Zungeru (1903-1923) and Lokoja (1897-1903). It is made up of some major towns which include: Zaria, Kagoro, Kafanchan, Kachia, Zonkwa, Makarfi and Birnin Gwari. (27) Kaduna State has coordinates of $10^{0} 20^{\prime} \mathrm{N} 7^{0} 45^{\prime} \mathrm{E}$ of Nigeria. It has a total land area of $46,053 \mathrm{~km}^{2}$ and a total population of $6,113,503$ according to the 2006 population census of Nigeria. (28) Kaduna State has over 1,000 primary healthcare facilities to cater for every resident - even in the most remote villages or political wards of the state. In addition to these, the government has made efforts to establish General hospitals in each of the 23 LGA headquarters to enhance effective and accessible healthcare for its citizens. These General hospitals have since become treatment centers for HIV anti retroviral therapy all around the state.

The survey recruited 158 discordant couples which amounted to 317 individuals. Kaduna State of Nigeria has 23LGAs and these LGAs were further grouped into three senatorial zones/ strata, out of which three LGAs were finally selected by simple random sampling from each senatorial zone. This stratified sampling technique resulted into 9LGAs from which we got the 317 individuals. These LGAs are: Kaduna north senatorial zone (Kudan, Lere and Soba), Kaduna central senatorial zone (Kajuru, K/north and Giwa), and Kaduna south senatorial zone (Kachia, Jema'a and Kagarko). Discordant couples who declined participation were not included. See Kaduna State Map here

https://drive.google.com/file/d/1eyNtIG3tVZLDOazH8nA88IpbhzWwi7_L/view?usp=sharing

\section{Sample collection}

\section{Ethical Consideration and Informed Consent}

The study was conducted according to ethical standards for human studies as approved by the research and ethics review committee of the Kaduna State Ministry of Health and Human Services. $\mathrm{MOH} / \mathrm{ADM} / 744 / \mathrm{VOL} .1 / 913$. Informed consent was obtained from all participants to take part in the 
study, after adequate explanations on the purpose, risk, method and benefit of the research. See link below for ethical clearance

https://drive.google.com/file/d/1_Jnlr30XLQWQVNwVoAZLWY39x2cbg-mB/view?usp=sharing

A structured questionnaire containing questions on demography and other required information was issued to all the respondents who were HIV positive, with adequate guidance on how to fill- in their responses correctly, and to invite their HIV negative partners for blood sampling. This took place during group information session (GIS). See link for questionnaire here

https://drive.google.com/file/d/1_uWS7jP01VAPzbf6pmtGcm61afmWKUc6/view?usp=sharing

For each of the couples determined above, blood samples (whole blood) of negative partners were collected by Laboratory staff of haematology department of the hospitals. HIV absence was confirmed using test kits (Rapid BTS, Rapid HIV 1 and 2 Home Test Kit/ DETERMINE). Blood samples were stored in the blood bank of the hospitals at $7^{\circ} \mathrm{C}$, and were later transported to DNA laboratory Kaduna in good conditioned ice packs for safe delivery. Further analysis for the presence of CCR5 D32 was conducted for the negative bloods in retrospect of CCR5 primer. Chi Square statistics and SPSS 21 was used for relevant statistical analysis.

\section{Optimization/pooling of blood samples}

This involved mixing some of the blood samples together (pooled) in one tube, and running the DNA extraction, PCR, and gel electrophoresis as 1 sample. The gel bands were expected to give a picture of a positive result, should it appear at the end of the main analysis. The optimization was done successfully and kept for future reference.

\section{DNA Extraction}

DNA was extracted using Accu prep Genomic DNA extraction kit from Bioneer. $20 \mu \mathrm{l}$ of proteinase K was added to each of 20 clean $1.5 \mathrm{ml}$ tubes. $200 \mu \mathrm{l}$ of whole blood was added to each of the 20 tubes containing proteinase K. $200 \mu \mathrm{l}$ of binding buffer (GC) was added to the samples and mixed immediately by vortex mixer. All of the mixture was then incubated at $60^{\circ} \mathrm{C}$ for $10 \mathrm{~min} .100 \mu \mathrm{l}$ of Isopropanol was added and mixed well by pippetting. After this step, the whole solution was spinned down to get the drops clinging under the lid. The lysate was carefully transferred into the upper reservoir of the binding column tube (fit in a $2 \mathrm{ml}$ tube) without wetting the rim. The tubes were closed and centrifuged at $8000 \mathrm{rpm}$ for $1 \mathrm{~min}$. The tubes were opened and the binding column tubes transferred to new $2 \mathrm{ml}$ tubes for filtration (supplied). 500 $\mu$ l of washing buffer1(W1) was added without wetting the rim, and all the tubes closed and centrifuged at $8000 \mathrm{rpm}$ for $1 \mathrm{~min}$. They were centrifuged again, at $12000 \mathrm{rpm}$ for $1 \mathrm{~min}$ to completely remove ethanol, and check that there is no droplet clinging to the bottom of the binding column tube. The binding column was transferred to a new $1.5 \mathrm{ml}$ tube for elution (supplied), $200 \mu$ l elution buffer added onto binding column tubes, and waited for $1 \mathrm{~min}$ at RT $\left(15-25^{\circ} \mathrm{C}\right)$ until elution buffer was completely absorbed into the glass fibre of binding column tubes. To increase DNA yield, there was a waiting for 
$5 \mathrm{~min}$ after adding elution buffer (EL), then the tubes were centrifuged at $8000 \mathrm{rpm}$ for $1 \mathrm{~min}$. to elute. About $180 \mu \mathrm{l}-200 \mu \mathrm{l}$ was obtained using $200 \mu \mathrm{l}$ Elution buffer (for improved yield, the elution was done twice). The eluted genomic DNA which was visible at the bottom of the tube was then used for PCR.

\section{Polymerase Chain Reaction (PCR)}

The PCR was conducted using Accupower Hotstart PCR premix, Bioneer. PCR primers (forward $\left(5^{\prime} \rightarrow 3^{\prime}\right)$ :AGGTACCTGGCTGTCGTCCA;reverse $\left(5^{\prime} \rightarrow 3^{\prime}\right)$ :CTCACAGCCCTGTGCCTCTTC) designed for an amplicon covering the 32 b.p. deletion of the CCR5 D32 with 329 or 297 b.p. in length, respectively was used. PCR- was conducted using the Thermal Cycler Model PTC 100. MJ Research. $2 \mu$ I DNA extract was

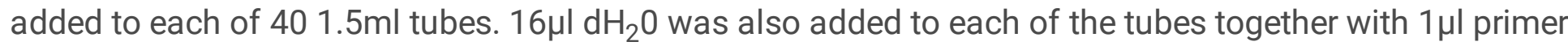
forward and $1 \mu$ primer backward primers (forward( $\left.5^{\prime} \rightarrow 3^{\prime}\right)$ :AGGTACCTGGCTGTCGTCCA;reverse $\left(5^{\prime} \rightarrow 3^{\prime}\right)$ : CTCACAGCCCTGTGCCTCTTC) designed for an amplicon covering the 32 b.p. deletion of

CCR5- $\triangle 32$ with 329 or 297 b.p. in length, respectively (Bioneer inc.). The thermal cycler condition was set as follows: Pre- Denaturation- $5 \mathrm{~min}$ at $95^{\circ} \mathrm{C}$, Denaturation- $30 \mathrm{sec}$ at $94^{\circ} \mathrm{C}$, Annealing- $30 \mathrm{sec}$ at $55^{\circ} \mathrm{C}$, Extention- $30 \mathrm{sec}$ at $72^{\circ} \mathrm{C} 35$ cycles, Final extention- $5 \mathrm{~min}$ at $72^{\circ} \mathrm{C}$. The procedure was repeated for all 159 DNA extracts.

\section{Gel Electrophoresis}

The amplified gene was run on a 1.5\% Agarose gel. The gel was prepared by weighing $3 \mathrm{~g}$ Agarose powder and dissolved in $200 \mathrm{ml} \mathrm{TAE}$ (Triple Acetate Electrolyte). The mixture was heat in a microwave oven until all Agarose was completely dissolved. The solution was allowed to cool in a water bath set at $50^{\circ} \mathrm{C}-55^{\circ} \mathrm{C}$. A gel casting tray was prepared by sealing ends of gel chamber with transparent selo tape. A 26 number comb was placed in the gel tray. While the gel was cooling, $5 \mu$ Ethidium bromide was added to the gel, mixed by shaking round and poured into the gel tray. It was allowed to cool for $30 \mathrm{~min}$ at room temperature, combs were removed and the gel placed in electrophoresis chamber and covered with buffer (TAE as used previously). 26 DNA extracts and standard Ladder (Bioneer inc.) were loaded onto the gel electrophoresis at $120 \mathrm{~V}$ for $1 \mathrm{hr}$. The DNA bands were viewed using UV light box (Biorad). The procedure was repeated for all the 159 samples.

\section{Sequencing}

The sequencing of CCR5 genes was done using sequencer model ABI 3100. Preparation of sequencing reaction was done in a $2 \mathrm{ml}$ tube in groups of 40 tubes each. All reagents were kept on ice while preparing the sequencing reactions. $9 \mu \mathrm{l}$ of $\mathrm{dH}_{2} \mathrm{O}$ was added into the tube, $9 \mu \mathrm{l}$ DNA extract was also added, $2 \mu \mathrm{l}$ of primers was equally added and $8 \mu$ l of Bigdye master mix added. All the mix was then put into the sequencing machine. The thermal cycling program was then set at: $96^{\circ} \mathrm{C}$ for $20 \mathrm{sec}, 50^{\circ} \mathrm{C}$ for $20 \mathrm{sec} X 30$ cycles, $60^{\circ} \mathrm{C}$ for $4 \mathrm{~min}$. 
Ethanol precipitation: A labeled sterile $0.5 \mathrm{ml}$ tube was prepared for each sample into which $5 \mu$ stop solution was added. Every one of the sequencing reaction was transferred into the appropriately labeled tube and mixed thoroughly. The stop solution contains $2 \mu \mathrm{l}$ of $3 \mathrm{M}$ Sodium acetate, $2 \mu \mathrm{l}$ of $100 \mathrm{mM} \mathrm{Na}_{2}-$ EDTA and $1 \mu \mathrm{l}$ of $20 \mathrm{mg} / \mathrm{ml}$ of glycogen (provided in the kit). $60 \mu \mathrm{l}$ cold $95 \%\left(\mathrm{v} / \mathrm{v}\right.$ ) ethanol from $-20^{\circ} \mathrm{C}$ freezer was added and mixed thoroughly. The mixture was immediately centrifuged at $14,000 \mathrm{rpm}$ at $4^{0} \mathrm{C}$ for $15 \mathrm{~min}$. the supernatant was carefully removed with a micropipette leaving a visible pellet. The pellet was rinsed with $200 \mu \mathrm{l} 70 \%(\mathrm{v} / \mathrm{v})$ ethanol from $-20^{\circ} \mathrm{C}$ freezer and centrifuged at $14,000 \mathrm{rpm}$ at $4^{0} \mathrm{C}$ for $2 \mathrm{~min}$. The supernatant was carefully removed again with a micropipette. It was then vacuum- dried for $10 \mathrm{~min}$. The sample was re-suspended in $40 \mu \mathrm{l}$ of the sample loading solution provided in the kit.

Sample preparation for Loading in to the Sequencer: The re- suspended samples were transferred to the appropriate wells of the sample plate. Each one of them was overlaid with one drop of mineral oil supplied in the kit. The sample plate was then finally loaded into the instrument and the sequencing started. The whole procedure was repeated for different sets until all the 159 samples were sequenced.

All chromographs/sequence plotting as read on the Flinch TV software after sequencing showed base pair readings as homozygous for CCR5 gene.

\section{Phylogenetic analysis}

The sequence obtained above was edited using the NCBI bioinformatics data software. Similar sequences were downloaded in FASTA format using BLAST N from the NCBI bioinformatics software. Downloaded sequences were aligned using MEGA 11 alignment software and evolutionary relationship eliminated at 1000 bootstrap.

\section{Results}

The results in Figure 1 shows that majority of women (66.46\%) were HIV positive than the men (33.54\%) hence the type of discordance in Kaduna State is "soft discordance". Even though the distribution of men to women in this research was 50: 50 (because they were husband and wife), the women were more positive for HIV than the men.

Table 1: Incidence of HIV Discordance in Kaduna State $(\mathrm{N}=317)$

Item Number of People Percentage (\%)

Total Population $\quad 6,115,503 \quad 100$

HIV Prevalence $\quad 67,271$

HIV Sero- discordance

159

0.2 
Table 1 shows $0.2 \%$ incidence for HIV discordance in Kaduna State.

The results in Figures 2 shows that all the blood samples had the CCR 5 gene except number 57 which means it had the CCR5 D32 allele. The 32 b.p. deletion has an approximate molecular weight 300bp which is visible on the bands when compared to the DNA ladder (Bioneer inc.). The gel picture shows that the DNA bands aligned at 300bp as expected.

\section{Table: 2 Frequency of CCR5 D32 gene among the studied Population}

\begin{tabular}{ccc}
\hline Gene Variant & Frequency & Percentage (\%) \\
\hline Wild Type (CCR5- wt) & 157 & 98.7 \\
Mutant Type (CCR5 D32) & 2 & 1.3 \\
\hline
\end{tabular}

Table 2 shows the frequency of CCR5 D32 gene in the population. Majority of the subjects $(98.7 \%)$ were homozygous for the wild type CCR5 gene. Only $1.3 \%$ of the studied population had the mutant CCR5 D32 gene.

The obtained CCR5 gene sequences from the respondents showed an exact match to BLAST sequences from data base of CCR5 genes as shown in Figure 3. The percentage similarity was between $90-100 \%$ in the BLAST mega search to existing sequences. The evolutionary distances shown on the tree reveals an evolutionary close relationship with trees of existing CCR5 genes, using the MEGA 11 software.

Figure 4 shows sequence alignment of CCR5 genes showing the few nucleotide polymorphisms. 


\section{Table 3: Correlation Between CCR5 D32, Use of ART, Sex \\ dependence and Discordance $(\mathrm{N}=317)$}

\begin{tabular}{cccc}
\hline Item & Yes (\%) & No (\%) & P-Value \\
\hline CCR5 D32 & $2(1.3)$ & $157(98.7)$ & 0.16 \\
Use of ART & $157(49.5)$ & $160(50.5)$ & $0.00^{*}$ \\
Sex Dependence & $\begin{array}{c}\text { Male (\%) } \\
158(49.8)\end{array}$ & $\begin{array}{c}\text { Female ( } \%) \\
159(50.2)\end{array}$ & 1.00 \\
\hline
\end{tabular}

*Statistically Significant Item

Table 3 shows that there is no significant relationship between CCR5 D32 and HIV discordance.

\section{Discussion}

Results of Figure 1 showed that in Kaduna State, more women $(66.46 \%)$ were HIV positive than their male counterparts (33.54\%). This means that in Kaduna State, women are two times more likely to be infected with HIV than men. This agrees with Magaji et al. (29) who reported similar incidence in Plateau State Nigeria. Biologically, women are two to eight times more likely than men to contract HIV during vaginal intercourse (30) and this is likely going to be the reason why our results somewhat agree with their report. We can also conclude that a large proportion of HIV discordance in Kaduna State is "soft discordance" according to Nnebue et al. (31) In other states of Nigeria, the case may be different as also reported by Nnebue et al. (31) A United Nations national report 2019 places Kaduna State on 1.1\% HIV prevalence, and Table 1 gives us a total of 159 respondents who were HIV negative out of the total 317 respondents. Using the figures above, the incidence of HIV discordance was calculated to be $0.2 \%$ for Kaduna State as shown in Table 1. This again agrees with Magaji et al. (29) who reported low incidence of serodiscordance in Plateau State, Nigeria. In Figure 2, the molecular analysis of blood samples showed that all of the blood samples, except two (1.3\%) were positive for CCR5 gene profiling- this shows clearly that $98.7 \%$ of discordant HIV subjects that participated in the study were positive for the normal allele/ wild type (CCR5- wt). The 1.3\% mutant gene (CCR5 D32) observed in the gel pictures, represents a few individuals that have the capacity to resist HIV infection in the population. (22) In order to confirm the authenticity of the gene amplification process carried out, the DNA extracts were sequenced, and the sequence results was entered into the NCBI real time software for bioinformatics and the confirmation showed that the gene of the respondents was a CCR5 complete sequence. The frequency of the CCR5 D32 gene in the population (1.3\%) shown in Table 2, disagrees with Solloch et al.(26) who reported a 0\% frequency in Africans; and agrees with other researchers $(24,25,23)$ who also stated that an estimated proportion of people with some form of resistance to HIV are fewer than $10 \%$. This goes to show that 
contrary to Solloch et al. (26) some few Africans do possess the CCR5 D32 allele gene. The 1.3\% frequency for CCR5 D32 mutant gene in Kaduna State also disagrees with Ekere et al. (32) who also reported a $0 \%$ frequency in Calabar, Cross river state where all the respondents had the CCR5 wt (wild type). The evolutionary relatedness of CCR5 gene seen in the samples studied; with those of already existing CCR5 genes confirm the predominance of HIV in the population as a result of persistent transmission of the virus from person to person. (32) Statistical analysis using SPSS 21 showed no correlation between CCR5 D32 and discordance, using available data as shown in Table 3. The high pvalue of 0.157 means there was no association between CCR5 D32 allele gene and the occurrence of HIV discordance, contrary to our initial expectations. This means that other factors may have been responsible for HIV discordance in the population as mentioned by Onovo et al. (4)

\section{Conclusion}

This research reaffirmed the existence of discordance among HIV infected couples in Kaduna State Nigeria; and revealed that more women $(66.46 \%)$ were positive than men $(33.54 \%)$. The discordance type was "soft discordance", and the incidence was found to be $0.2 \%$ of the infected population. The CCR5 D32 allele gene frequency in Kaduna State was also found to be $1.3 \%$ contrary to initial expectations of a $0 \%$ frequency. But because with or without CCR5 D32 allele gene the population still had discordance, we can conclude that there was no correlation between CCR5 D32 and HIV discordance in Kaduna State Nigeria, using available data. It will therefore be recommended that more of this survey be conducted in other states of Nigeria, and even extend the work to other African countries. Probably, a high frequency of the CCR5 D32 allele gene in the population will open a new vista of hope in the eventual discovery of a final solution to the problem of HIV and AIDS.

\section{Declarations}

Ethics approval and consent to participate- The study was conducted according to ethical standards for human studies as approved by the research and ethics review committee of the Kaduna State ministry of Health and Human Services. MOH/ADM/744/VOL.1/913. See document here https://drive.google.com/file/d/1_Jnlr30XLQWQVNwVoAZLWY39x2cbg-mB/view?usp=sharing

Informed consent was obtained from all participants to take part in the study, after adequate explanations on the purpose, risk, method and benefit of the research. LINK https://drive.google.com/file/d/1_uWS7jP01VAPzbf6pmtGcm61afmWKUc6/view?usp=sharing

Consent for Publication- Consent was received from participants. See LINK https://drive.google.com/file/d/1eVGYJ7F-QOuDfrfiN7o9B10PjPHvrOBs/view?usp=sharing

Availability of data and materials- The dataset used and /or analysed in the current study are available from the corresponding author on reasonable request.

Competing interests- The authors declare that they have no competing interests. 
Funding- No funding was received from anywhere.

\section{Authors' contributions}

Danboyi D.A. conceived the study and participated in its design and coordination.

Sani M.N and Danboyi D.A. conducted the statistical analysis.

Danjuma $\mathrm{L}$ and Abdullahi $\mathrm{M}$ handled the study review.

All authors read and approved the final manuscript

\section{Acknowledgements}

The authors wish to appreciate the support of the Kaduna State ministry of health for making their facilities and staff available for this study. The Clients who visited these treatment centers to access antiretroviral treatment are also recognized for their cooperation.

\section{References}

1. Matovu JK. Preventing HIV transmission in married and cohabiting HIV- discordant couples in subSaharan Africa through combination prevention. Current HIV Res. 2010;8:430- 440. DOI: $10.2174 / 157016210793499303$

2. Curran K, Baeten J, Coates T, Kurth A, Mugo N, Celum C. HIV- 1 prevention for HIV- 1 serodiscordant couples. Current HIV/AIDS rep 2012; 9:160- 170. doi: 10.1007/s11904-012-0114-z

3. Mazzota M. WHO issues new guidelines for discordant couples. Science Speaks 2012: Global ID News. Accessed July 5,2020.http://whqlibdoc.who.int>9789241501972_eng

4. Onovo AA, Nta IE, Onah AA et al. Partner HIV serostatus disclosure and determinants of serodiscordance among prevention of mother to child transmission clients in Nigeria. BMC Public health 2015;15:827.https://doi.org/ 10.1186/s12889-015-2155-x

5. Jiao X, Nawab O, Patel T, Kossenkov AV, Halama N, Jaeger D et al. Recent Advances Targeting CCR5 for Cancer and Its Role in Immuno- Oncology. Cancer Res 2019;79 (19):4801-4807. https://doi.org/10.1158/0008-5472.CAN-19-1167

6. de Silva E, Stumpf MP. HIV and the CCR5-Delta32 resistance allele. FEMS Microbiology Letters 2004;241 (1): 1- 12. https://doi.org/10.1016/j.femsle.2004.09.040

7. Hütter G, Nowak D, Mossner M, Ganepola S, Müssig A, Allers $K$ et al. Long-term control of HIV by CCR5 Delta32/Delta32 stem-cell transplantation. N Engl J Med 2009;360(7):692-8. https://doi.org/10.1056/NEJMoa0802905

8. Allers K, Hütter G, Hofmann J, Loddenkemper C, Rieger K, Thiel E et al. Evidence for the cure of HIV infection by $C C R 5 \Delta 32 / \Delta 32$ stem cell transplantation. Blood 2011; 117(10):2791- 9 . 
https://doi.org/10.1182/blood-2010-09-309591

9. Zhen A, Kitchen S. Stem-cell-based gene therapy for HIV infection. Viruses 2014;6 (1): 1-12. https://doi.org/10.3390/v6010001

10. Kay M A, Walker BD. Engineering cellular resistance to HIV. N Engl J Med 2014;370 (10):968- 9. https://doi.org/10.1056/NEJMe1400593

11. Tebas P, Stein D, Tang WW, Frank I, Wang SQ, Lee G. et al. Gene editing of CCR5 in autologous CD4 T cells of persons infected with HIV. N Engl J Med 2014;370 (10):901-10. https://doi.org/10.1056/NEJMoa1300662

12. Samson M, Labbe O, Mollereau C, Vassart G, Parmentier M. Molecular cloning and functional expression of a new human CC-chemokine receptor gene. Biochemistry 1996; 35 (11):33627. https://doi.org/10.1021/bi952950g

13. Velasco-Velázquez M, Jiao X, De La Fuente M, Pestell TG, Ertel A, Lisanti MP. et al. CCR5 antagonist blocks metastasis of basal breast cancer cells. Cancer Res 2012;72 (15):383950. https://doi.org/10.1158/0008-5472.CAN-11-3917

14. Sicoli D, Jiao X, Ju X, Velasco-Velazquez M, Ertel A, Addya S. CCR5 receptor antagonists block metastasis to bone of v-Src oncogene- transformed metastatic prostate cancer cell lines. Cancer Res 2014;74 (23):7103- 14.https://doi.org/10.1158/0008- 5472.CAN-14-0612

15. Galvani AP, Slatkin M. Evaluating plague and smallpox as historical selective pressures for the CCR5Delta 32 HIV-resistance allele. PNAS 2003;100 (25):15276- 9. https://doi.org/10.1073/pnas.2435085100

16. Stephens JC, Reich DE, Goldstein DB, Shin HD, Smith MW, Carrington M et al. Dating the origin of the CCR5-Delta32 AIDS-resistance allele by the coalescence of haplotypes. Am J Hum Genet 1998;62 (6):1507- 15. https://doi.org/10.1086/301867

17. Dean M, Carrington M, Winkler C, Huttley GA, Smith MW, Allikmets R. et al. Genetic restriction of HIV-1 infection and progression to AIDS by a deletion allele of the CKR5 structural gene. Hemophilia Growth and Development Study, Multicenter AIDS Cohort Study, Multicenter Hemophilia Cohort Stud y, San Francisco City Cohort, ALIVE Study. Science 1996;273 (5283):1856- 62. https://doi.org/10.1126/science.273.5283.1856

18. Liu R, Paxton WA, Choe S, Ceradini D, Martin SR, Horuk R. et al. Homozygous defect in HIV-1 coreceptor accounts for resistance of some multiply-exposed individuals to HIV-1 infection. Cell 1996;86(3):367-77. https://doi.org/10.1016/s0092-8674(00)80110-5

19. Benkirane M, Jin DY, Chun RF, Koup RA, Jeang KT. Mechanism of transdominant inhibition of CCR5mediated HIV-1 infection by ccr5delta32. J Bio Chem 1997;272 (49):30603- 6. https://doi.org/10.1074/jbc.272.49.30603

20. Michael NL, Louie LG, Rohrbaugh AL, Schultz KA, Dayhoff DE, Wang CE et al. The role of CCR5 and CCR2 polymorphisms in HIV-1 transmission and disease progression. Nat Med 1997;3 (10):1160- 2. https://doi.org/10.1038/nm1097-1160 
21. Laurichesse JJ, Persoz A, Theodorou I, Rouzioux C, Delfraissy JF, Meyer L. Improved virological response to highly active antiretroviral therapy in HIV-1-infected patients carrying the CCR5 Delta32 deletion. HIV Medicine 2007;8 (4):213-9 https://doi.org/10.1111/j.1468-1293.2007.00455.x

22. Scutti S. Why Some People Are Naturally Immune To HIV. Medical Daily 2014.Retrieved 2020- 05- 25. Available from https://en.wikipedia.org>wiki>innate_resistance_to_HIV

23. Ring T. Is Anyone Immune to HIV. HIV Plus Mag. 2012. Retrieved 2020-05-25. Available from:https://en.wikipedia.org>wiki>Timothy_Ray_Brown

24. Nolen S. Staying alive: the women who are immune to Aids. The Guardian2007. Retrieved 2020-0529. Available from:https://www.theguardian.com>may>aids. features

25. Angelle A. Immune to HIV: How Do They Do It. Live Science 2010-07-21. Retrieved 2020- 05-29. Available from:https://www.livescience.com>9983-immune-hiv

26. Solloch UV, Lang K, Lange V, Bohme I, Schmidt AH, Sauter J. Frequency of gene variant of CCR5 D32 in 87 countries based on next generation sequencing of 1.3 million individuals sampled from 3 national DKMS centers. Hum Immunol 2017; 78:710- 717.

27. Kaduna State- Explore Nigeria Explorenigeria.com:ng/states/Kaduna-state/ 2020.Retrieved From Wikipedia

28. NPC. 2006 PHC Priority Tables- NATIONAL POPULATION COMMISSION. population.gov.ng. Achieved from the original on 2017-10-10. Retrieved 2020- 06- 13. https://en.wikipedia,org>wiki>List_of_Nigerian_state

29. Magaji FA, Ocheche AN, Pam VC et al. HIV status in sero- discordant couples: Prevalence and Pattern among pregnant women in Plateau State, Nigeria. J Clinical Res HIV AIDS Prev 2018;3(2):33- 40. DOI 10.14302/issn.2324-7339.jcrhap-18-2236

30. Cummins JE, Dezzutti CS. Sexual HIV-1 Transmission and Mucosal Defense Mechanisms. AIDS Review 2000;2:144-154, cited by amfAR, The Foundation for AIDS Research, Fact Sheet: Woman and HIV/AIDS. March 2008. Accessed June 10, 2020. https://iwhc.org>wp-content>uploads>2016/10

31. Nnebue C, Anaekwe A, Anaekwe C. Sociodemographic Correlates of HIV discordant and Concordant couples in Anambra State, Nigeria. Ethiop J Health Sci. 2017;27(4):363-372.doi: 10.4314/ejhs.v27i4.7

32. Ekere EF, Useh MF, Okoroiwu HU, Mirabaeu TY. Cysteine- cysteine Chemokine Receptor 5 (CCR5) Profile of HIV-infected subjects attending University of Calabar Teaching Hospital, Calabar, Southern Nigeria. BMC Infectious Diseases 2020;20(5):1- 9. https://doi.org/ 10.1186/s12879-0194737-1.

\section{Figures}




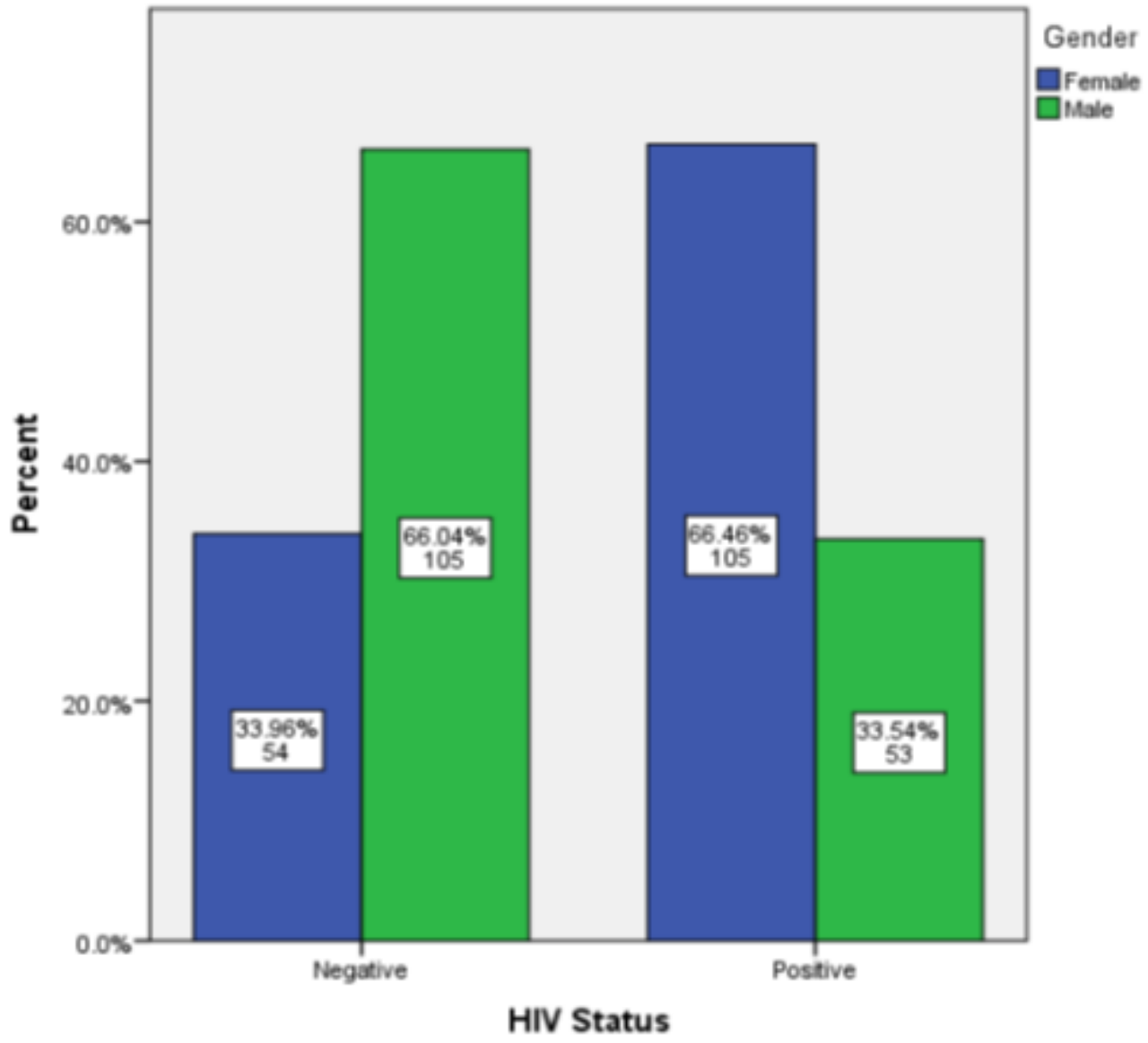

Figure 1

HIV Status of Respondents 


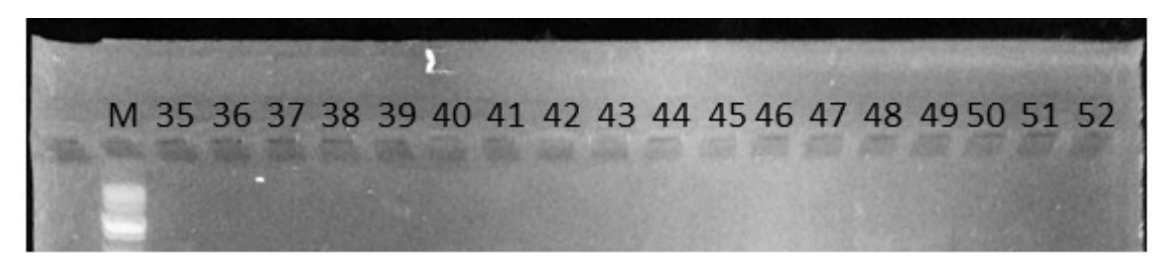

Figure 2

Visible Bands of CCR5 Gene, showing one blank CCR5 D32 mutant allele. 


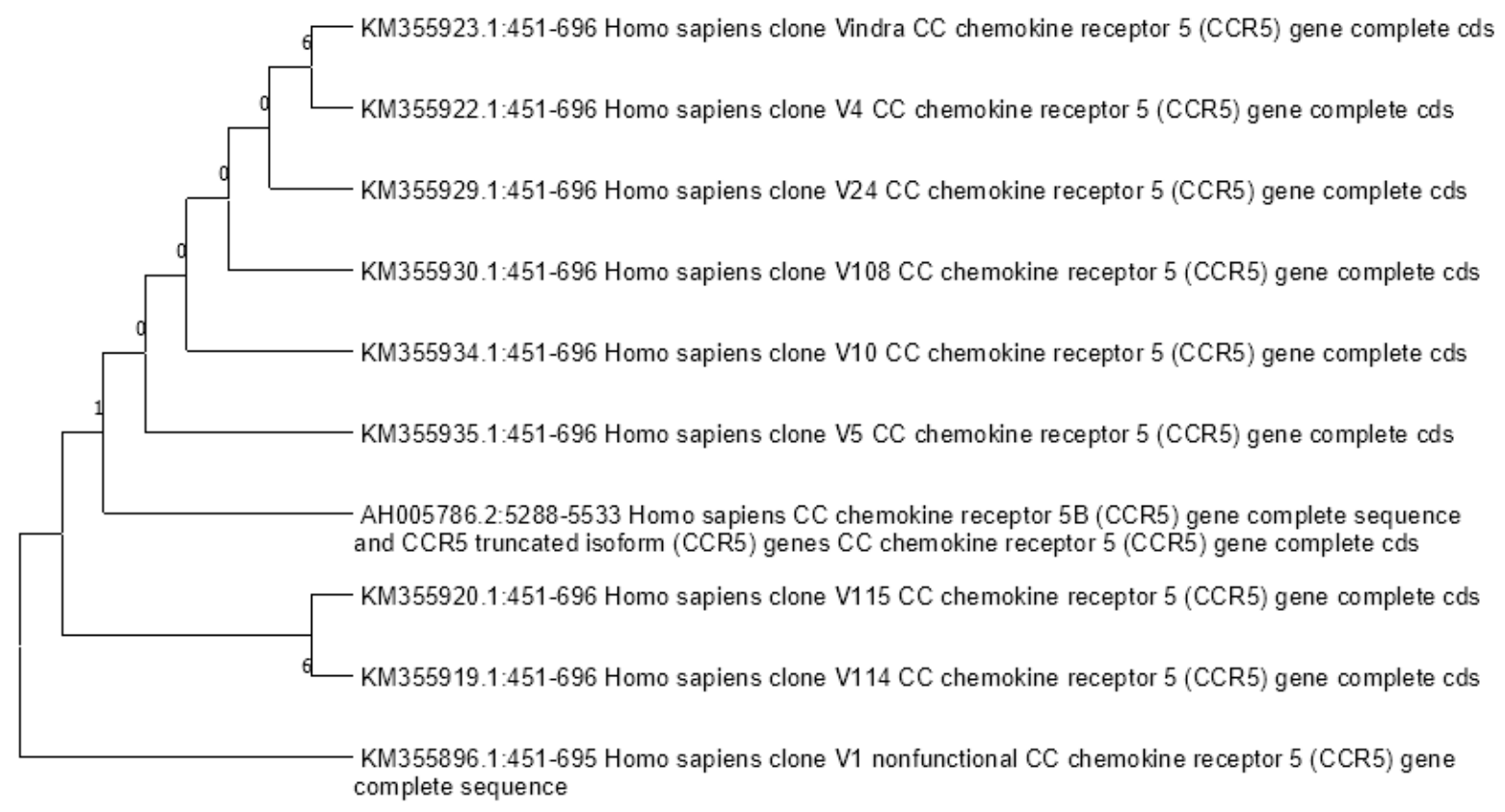

\section{Figure 3}

Phylogenetic tree showing genetic relationship between CCR5 genes

\section{Figure 4}

Sequence Alignment of CCR5 genes showing nucleotide polymorphism 